\section{Active Nitrogen and the Auroral Spectrum}

Is my letter in a recent number of NATURE ${ }^{1}$ I described an afterglow in nitrogen in which the first negative bands of $\mathrm{N}_{2}$ were present, and in which the excitation of the first positive bands was different from that hitherto observed in nitrogen afterglows. At the time the letter was written, no photograph of the afterglow intense enough to print had been obtained. Fig. 1 shows a photograph of the spectrum of the afterglow which has been obtained since then, and it is to be noted that with the exception of the green auroral line, the afterglow spectrum is remarkably like the auroral spectrum. In my first letter it was stated that the second positive bands were completely missing from the afterglow, and that

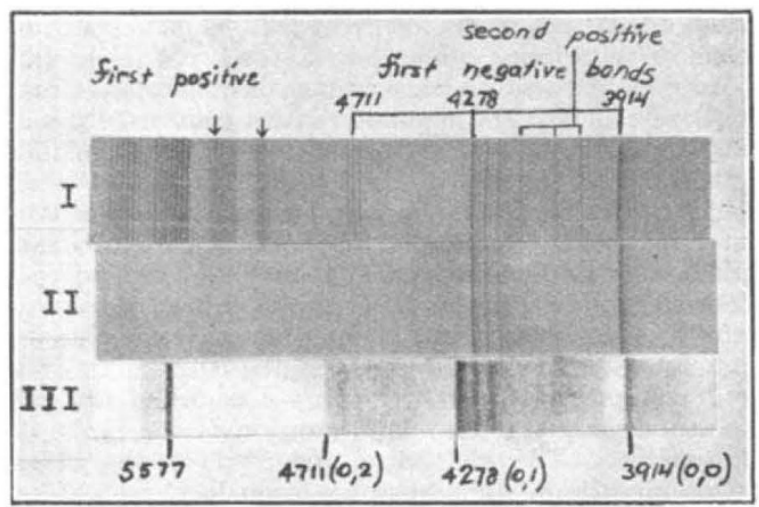

FiG. 1. I, Direct discharge (panchromatic plate); II, afterglow (Eastman astronomical green plate); III, aurora borealis (dispersion different from' $I$ and II).

was true of the plate which was described in that letter, but a trace of the second positive group can be very easily seen on the present plate and they have been obtained with considerable intensity on a plate taken on a small quartz Hilger spectrograph. The arrows on Fig. $l$ point to first positive band sequences which originate on $V^{\prime}=16,17,18$, etc., and it is seen that these sequences are present on the afterglow plates also.

Further experiments are now in progress in order to obtain better pictures of the first positive bands in the green, red and the photographic infra-red.

University of California at Los Angeles. JOSEPH KAPLAN.

Jan. 12.

${ }^{2}$ Kaplan, Nature, 132, 1002, Dec. 30, 1933.

\section{Age of Sub-Crag Implements}

Mr. J. ReID MoIr has recently directed attention to an interesting series of worked flints found beneath the Red Crag, exhibited at present in the British Museum ${ }^{1}$. Adhering to one of these flints is some ferruginous sandy material which $\mathrm{Mr}$. Moir regards as Diestian, since it resembles the sandstone of which the well-known Suffolk Boxstones are composed. Thanks to the courtesy of Mr. Reginald Smith, I have had an opportunity of examining this specimen. The encrusting material is an iron-cemented sand which appears to me to bear a stronger resemblance to Red Crag sand than to Boxstone material. The quantity of sand is too small to permit mineralogical analysis; moreover, such a process would destroy the evidence. Even if it were proved to be Boxstone detritus, the possibility of its having been re-deposited in Red Crag times would have to be seriously considered.

Mr. Moir bases interesting speculations on the possibility of the rostro-carinate implement in question being pre-Diestian, that is, pre-Pliocene. In this connexion, it is important to bear in mind that the British representatives of the Continental Diestian deposits are the Lenham Beds (Early Pliocene) of Kent and Sussex, and not the Boxstones of Suffolk, as Mr. Moir states. Our knowledge of the fauna of the Lenham Beds has been increased by discoveries made during the last few years, and recent investigations have served to emphasise the greater age of the Boxstone fauna. The latter is regarded by many geologists as Miocene; in fact, some of the mollusca are apparently related to Upper Oligocene forms. Mr. Moir's arguments would therefore imply that the maker of the rostro-carinate implement lived in times not later than the Miocene.

\author{
Imperial College of Stcience \\ and Technology, \\ South Kensington, \\ London, S.W.7. \\ Feb. 13. \\ ${ }^{1}$ Nature, 133, 64, Jan. 13, 1934.
} P. G. H. Boswer.,

\section{Ernst Haeckel}

MANY scientists will have read with keen interest Prof. MacBride's delightful sketch of Haeckel's work in NATURE of February 10. As he points out, Haeckel's career belongs to the heroic stage of the history of the theory of evolution; certainly few men have been subjected to greater obloquy for promulgating that or any other doctrine. When his "General Morphology" appeared, it was met with "icy silence" - a reception which the impetuous and combative Haeckel could not tolerate. He would have preferred hostile criticism, rather than indifference; and to this indifference on the part of his fellow-scientists can be traced the commence. ment of that series of popular works on evolution which were met, not with "icy silence", but with fiery blasts from scientists and laymen alike.

At one period of the controversy, Haeckel felt that his presence at Jena was jeopardising the good name of his beloved university, so he offered to resign his chair; but the head of the governing body replied : "My dear Haeckel, you are still young, and you will yet come to have more mature views of life. After all, you will do less harm here than elsewhere, so you had better stop here." In point of fact, Jena never forsook Haeckel and Haeckel never forsook Jena, despite the flattering offers he received from the Universities of Vienna, Würzburg, Bonn and Strasbourg; and he died there, not in 1914 as mentioned by Prof. MacBride, but on August 8, 1919. An obituary notice appeared in NATURE of August 21, 1919.

11, Millmoor Terrace,
Glossop, Derbyshire.

W. H. BRINDlEY. Feb. 9.

I AM sorry that I made a slip in giving the date of Haeckel's death. I thank Dr. Brindley for correcting me.

E. W. M. 